\title{
TIBIAL ADAMANTINOMA: ANALYSIS OF SEVEN CONSECUTIVE CASES IN A SINGLE INSTITUTION
}

\section{ADAMANTINOMA DA TÍBIA: ANÁLISE DE SETE CASOS CONSECUTIVOS EM UMA ÚNICA INSTITUIÇÃO}

\author{
Juan Pablo Zumárraga ${ }^{1}$, Ricardo Cartolano $^{2}$, Marcelo Tomio Kohara ${ }^{1}$, André Mathias Baptista ${ }^{1}$, Felipe Gonçalves dos Santos ${ }^{1}$, \\ Olavo Pires de Camargo ${ }^{1-3}$
}

1. Orthopedic Oncology Group, Instituto de Ortopedia, Hospital das Clinicas HCFMUSP, Faculdade de Medicina, Universidade de São Paulo, São Paulo, SP, Brazil. 2. Instituto de Ortopedia, Hospital das Clinicas HCFMUSP, Faculdade de Medicina, Universidade de São Paulo, São Paulo, SP, Brazil.

3. Department of Orthopedics and Traumatology, Faculdade de Medicina, Universidade de São Paulo, São Paulo, SP, Brazil.

\section{ABSTRACT}

Objective: Adamantinoma accounts for less than $1 \%$ of the primary bone neoplasms. The tibia is the most affected bone and it is predominant in male patients between the second and third decades of life. The objective of this study is to obtain epidemiological and clinical information on patients with adamantinoma of the tibia treated surgically between 1989 and 2016. Methods: Retrospective series of seven patients diagnosed with adamantinoma of the tibia that underwent surgery at the orthopedic oncology service of our hospital. The information was obtained from the medical records and histopathological reports of our institution. Results: A total of 2870 medical records with histological reports were evaluated. Seven cases of adamantinoma of the tibia were included. The mean age was 28.5 (17-49) years. We found a predominance of females $(71.4 \%)$ and the most affected side was the left one, with four cases (57.1\%). The biopsy revealed bone adamantinoma in four (57.1\%) patients, while the diagnosis of the other patients was confirmed after the histological examination of the surgical specimen. All the patients underwent surgery as definitive treatment. No positive margins were reported. No local recurrence (LR) was reported and two patients had distant metastasis (DM). Conclusion: The prognosis of survival in cases of adamantinoma of the tibia is high. The rates of LR and DM were low. Surgical treatment with extensive tumor resection is the treatment of choice. Level of Evidence IV, Case Series.

Keywords: Adamantinoma. Tibia. Bone neoplasms. Biopsy. Surgical oncology.

\section{RESUMO}

Objetivo: O adamantinoma representa menos de 1\% das neoplasias ósseas primárias. Afeta predominantemente a tíbia, em pacientes do sexo masculino entre a segunda e terceira décadas da vida. $O$ objetivo deste trabalho é obter informação epidemiológica e clínica dos pacientes com adamantinoma da tíbia, tratados mediante cirurgia entre 1989 e 2016. Métodos: Série retrospectiva de sete pacientes com diagnóstico de adamantinoma da tíbia, tratados cirurgicamente no serviço de oncologia ortopédica do nosso hospital. A informação foi obtida dos relatos clínicos e patológicos do instituto. Resultados: Um total de 2870 prontuários com relatos anatomopatológicos foram revisados. Sete casos de pacientes com adamantinoma na tíbia foram encontrados. A média de idade foi de 28,5 anos (17-49). Encontramos predominância do sexo feminino (71,4\%). O lado mais afetado foi o esquerdo, com quatro (57,1\%) casos. A biópsia diagnosticou adamantinoma em $57,1 \%$ dos casos e o diagnóstico dos outros casos foi definido após exame da peça cirúrgica. Todos os pacientes receberam tratamento cirúrgico como terapia definitiva. Não foram reportadas margens comprometidas. Nenhum paciente apresentou recorrência local (RL). Dois pacientes apresentaram metástase à distância (MD). Conclusão: O prognóstico de sobrevida do adamantinoma da tíbia é alto. Apresenta taxas baixas de RL e MD. A cirurgia com ampla ressecção do tumor é o tratamento de escolha. Nível de Evidência IV, Série de Casos.

Descritores: Adamantinoma. Tíbia. Neoplasias ósseas. Biópsia. Oncologia cirúrgica.

Citation: Zumárraga JP, Cartolano R, Kohara MT, Baptista AM, Santos FG, Camargo OP. Tibial adamantinoma: analysis of seven consecutive cases in a single institution. Acta Ortop Bras. [online]. 2018;26(4):252-4. Available from URL: http://www.scielo.br/aob.

\section{INTRODUCTION}

Adamantinoma is a rare cancerous tumor, accounting for less than $1 \%$ of all primary bone tumors. ${ }^{1}$ The World Health Organization (WHO) defines it as a biphasic tumor, characterized by a variety of morphological patterns. The most common histological pattern appears as a cluster of epithelial cells, surrounded by an osteofibrous cell component. ${ }^{2}$ It primarily affects patients in their 20 s and 30 s, who are predominantly male. ${ }^{3}$ The tibia is the most commonly affected site (85\% of reports). ${ }^{4,5}$ Pain is the main patient-reported symptom. ${ }^{6}$ Histologically, it is a neoplasm originating from aberrant

All authors declare no potential conflict of interest related to this article.

Work conducted at the Instituto de Ortopedia, Hospital das Clinicas HCFMUSP, Faculdade de Medicina, Universidade de São Paulo, São Paulo, SP, Brazil. Correspondence: Juan Pablo Zumárraga. Rua Ovídio Pires de Campos, 333, Cerqueira Cesar, São Paulo, SP, Brazil. 05403-010. juanpzumarraga@ @hotmail.com 
epithelial cells, with spindle-cell osteofibrous component. It can appear in four different patterns: basaloid, tubular, fusiform, and squamous. The basaloid and tubular types are the most common, and usually have a low mitotic index. ${ }^{2,7,8}$ Radiography generally has an aggressive pattern, with radiolucent areas interspersed with poorly delimited sclerotic areas, which is known as the soap bubble pattern. ${ }^{8}$ The most important differential diagnosis is osteofibrous dysplasia (OD) ${ }^{1,9-12}$ There are some publications in the literature which advocate the possibility that OD is a precursor lesion to adamantinoma. ${ }^{1}$ The post-biopsy pathological result often defines the lesion as OD. However, the final study of the surgical specimen determines the diagnosis of adamantinoma. This divergence of initial diagnosis supports the hypothesis formulated above. ${ }^{13,14}$ Treatment of adamantinoma is based on extensive resection of the lesion with reconstruction of the bone defect (Figure 1). Several procedures described in the literature can be used: autograft, endoprosthesis, allograft and bone transport. , $13-16$ Because it is a lesion of low histologic grade, radical surgery with amputation should be ruled out whenever possible. Neoadjuvant or adjuvant chemotherapy (CT) and radiotherapy (RT) are not recommended in the literature. ${ }^{17}$ LR (local recurrence) and DM (distant metastasis) are rare. When present, DM primarily affects the lung. We also find reports of DM in the lymph nodes and bone, of extremely rare occurrence and late presentation. ${ }^{16,18}$ This study reports on a series of seven consecutive cases of patients diagnosed with adamantinoma in the tibia and treated surgically at a single institution. Thus, the purpose of this study was to describe the follow-up and outcome of these cases in view of the fact that it is a rare diagnosis with limited literature.

\section{MATERIALS AND METHODS}

The study was approved by the Institutional Review Board of HCFMUSP under number 14148. It is a retrospective study in which seven medical records of patients diagnosed with adamantinoma of the tibia by the Orthopedic Oncology Group of IOT-HC-FMUSP between 1989 and 2016 were used. All patients included in this

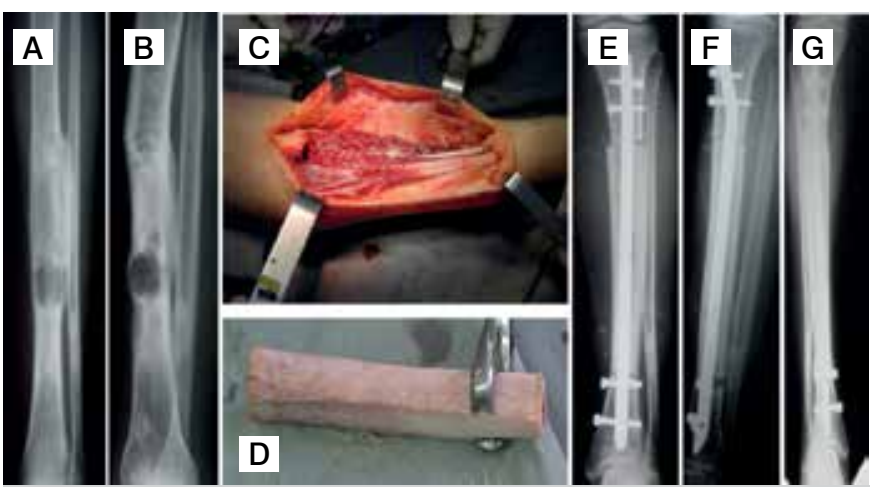

Figure 1. Case 3. Adamantinoma of the Tibia. Treatment with Allograft. A-B: Initial AP + Lat. X-ray. C: Surgical resection. D: Allograft. E-F: Reconstruction of the bone defect with allograft. G: 15 years after surgery, consolidation of the allograft. study received surgical treatment. Age, sex, initial symptomatology, date of diagnosis, clinical stage, radiological characteristics, type of surgery and postoperative outpatient follow-up were acquired from the medical records. The histological diagnosis was made by the pathologists of the institute. Clinical and demographic characteristics were described using the following measures: mean, median, minimum and maximum for quantitative variables, and absolute and relative values for qualitative variables. ${ }^{19}$ Clinical symptoms, histological presentation, treatment and results were described.

\section{RESULTS}

A total of 2870 medical records with pathology reports were reviewed for this study. Only seven cases of adamantinoma of the tibia were found (Table 1). The mean age was 28.5 years (17-49). Five patients were female (71.4\%) and two male (28.5\%). The mean time from onset of symptoms to surgical treatment was 33.6 months. The left side was affected the most. Pain was the clinical characteristic present in all patients. We observed deformity of the tibia in six (85.7\%) cases. Antecurvatum deformity was standard for these cases. Radiographic examination, with frontal and lateral views of the leg, respected the characteristic findings of the lesion, with a mean of $9.16 \mathrm{~cm}(4.1-12.8)$. The biopsy defined the diagnosis of adamantinoma in four (57.1\%) cases. OD was reported in two (28.5\%) cases and one (14.2\%) case was reported as non-specific fibrosis. After the study of the surgical specimen, all cases were reported as adamantinoma. All patients received surgical treatment as definitive therapy at the institute. The surgery of choice for all patients was extensive resection of the bone lesion. Allograft reconstruction was performed in five (71.4\%) cases and nonconventional diaphyseal endoprosthesis of the tibia in two (28.5\%) cases. Two (28.5\%) cases progressed to amputation. We had complication of skin and deep soft tissues (infection) in one $(14.2 \%)$ case involving reconstruction with non-conventional diaphyseal endoprosthesis of the tibia. The infection, uncontrolled after extensive treatment with antibiotic therapy, progressed to disarticulation of the knee. Two (28.5\%) cases had DM: one (14.2\%) case in the inguinal lymph nodes in which the lesion was resected, and one (14.2\%) case in the ipsilateral proximal femur. The case with bone metastasis progressed to disarticulation of the hip. No patient in this series had compromised surgical margins or LR. Furthermore, none of the patients in this study died. The mean follow-up time was 180 months (36-324).

\section{DISCUSSION}

The medical literature does not contain an extensive volume of publications on adamantinoma, mainly because of the rarity of this disease. Most published studies are retrospective series and case reports. This was no exception: we analyzed seven consecutive cases over 29 years. We did not find studies on this topic in our field. The mean age of our study was 28.5 years, which coincides with that described in the literature., ${ }^{1,3}$ Although accordingly to bibliographical references the disease is be more predominant in male

Table 1. Distribution of cases in chronological order.

\begin{tabular}{c|c|c|c|c|c|c|c|c}
\hline Case & Age $^{*}$ & Size & Year of Surgery & Surgical Margins & Reconstruction & Complications & Local Recurrence & Metastasis \\
\hline 1 & 58 & $9.3 \times 5.8 \times 4.2$ & 1989 & negative & allograft & no & no & no \\
\hline 2 & 48 & $10.2 \times 5.3 \times 4.8$ & 1994 & negative & endoprosthesis & no & no & yes \\
\hline 3 & 57 & $11.4 \times 6.1 \times 5.2$ & 2000 & negative & allograft & no & no & no \\
\hline 4 & 53 & $9.6 \times 5.8 \times 4.1$ & 2001 & negative & endoprosthesis & infection & no & no \\
\hline 5 & 41 & $13.5 \times 5.9 \times 5.1$ & 2003 & negative & allograft & no & no & no \\
\hline 6 & 21 & $7.3 \times 4.9 \times 4.2$ & 2012 & negative & allograft & no & no & no \\
\hline 7 & 17 & $11.8 \times 5.6 \times 4.9$ & 2014 & negative & allograft & metastasis & no & yes \\
\hline
\end{tabular}

Current age of the patient, ${ }^{*}$ size in $\mathrm{cm}$ of the surgical specimen ${ }^{\star *}$. 
patients, ${ }^{3}$ in this we observed predominance of female patients (71.4\%). Published studies indicate that $85 \%$ of adamantinoma cases occur in the tibia., ${ }^{4,5}$ This data cannot be compared since this study analyzed cases located only in the tibia. We found pain to be the main symptom of the disease, coinciding with the description presented in the publications. ${ }^{4,5,6}$ In the literature, there are reports of different histopathological diagnoses in the biopsy, when compared with that of the surgical specimen. An initial diagnosis of OD is a common occurrence..$^{13}$ In this study, we also obtained this divergence, two (28.5\%) cases obtained an initial diagnosis of OD. The common histogenetic origin between OD, osteofibrous dysplasia-like adamantinoma- and adamantinoma hinders the post-biopsy histopathological diagnostic definition. ${ }^{20}$ Clinical, histopathological and imaging correlations should be compared for an adequate definition of the treatment. As defined in the literature, the treatment of choice for all cases was extensive resection with reconstruction. Complications of surgical treatment of adamantinoma can affect
$66.6 \%$ of cases. The most common complications are infection, allograft consolidation failure, and fracture. ${ }^{21,22}$ In this case series, we obtained a lower rate of complications than that found in the literature. We reported one (14.2\%) case of infection. Moreover, we did not report any cases that presented with LR. In the literature, we can see that the LR rate is as high as $30 \% .^{21}$ For DM we presented a rate of $14.2 \%$, which is similar to the rate published, since reports describe a $15 \%$ rate of metastasis. ${ }^{21}$ Adamantinoma has a high survival rate, with reports ranging between 85 and $95 \%$ at 5 years. ${ }^{23}$ This is another difference of our study, in which we obtained a $100 \%$ survival rate. Finally, multicenter studies are needed to optimize the diagnosis and to define treatment protocols for adamantinoma.

\section{CONCLUSIONS}

The prognosis of survival of adamantinoma in the tibia is high. It has low LR and DM rates. Surgical treatment with extensive resection of the tumor continues to be the standard therapeutic choice.

AUTHORS' CONTRIBUTIONS: Each author made significant individual contributions to this manuscript. JPZ (0000-0001-5941-7714) , RC (0000-00027853-1325)* , MTK (000-0003-3384-7905)* , AMB (0000-0002-0830-4602)* , FGS (0000-0002-6854-6072)*, and OPC (0000-0002-1128-7292)*, were the main contributors in writing this work. JPZ participated in: research, design, writing and data collection; RC participated in: concept, research, writing and data collection; MTK participated in: concept, research, writing and data collection; AMB participated in: concept, design, and analysis; FGS participated in: research, design and data collection; OPC participated in: concept, writing and analysis. *ORCID (Open Researcher and Contributor ID).

\section{REFERENCES}

1. Mavrogenis AF, Sakellariou VI, Tsibidakis H, Papagelopoulos PJ. Adamantinoma of the tibia treated with a new intramedullary diaphyseal segmental defect implant. J Int Med Res. 2009;37(4):1238-45.

2. Hogendoorn PCW, Kanamori M. Adamantinoma. In: Fletcher CDM, Bridge JA, Hogendoorn PCW, Mertens F.WHO classification of tumors of soft tissue and bone. 4th. Lyon: International Agency for Research on Cancer; 2013. p. 343-45.

3. Moon NF, Mori H. Adamantinoma of the appendicular skeleton updated. Clin Orthop Relat Res. 1986;(204):215-37.

4. Czerniak B, Rojas-Corona RR, Dorfman HD. Morphologic diversity of long bone adamantinoma. The concept of differentiated (regressing) adamantinoma and its relationship to osteofibrous dysplasia. Cancer. 1989;64(11):2319-34.

5. Keeney GL, Unni KK, Beabout JW, Pritchard DJ. Adamantinoma of long bones A clinicopathologic study of 85 cases. Cancer. 1989;64(3):730-7.

6. Jain D, Jain VK, Vasishta RK, Ranjan P, Kumar Y. Adamantinoma: a clinicopathological review and update. Diagn. Pathol. 2008;15(3):8.

7. Fisher B. Primary adamantinoma of the tibia. Z Pathol. 1913;12:422-41.

8. Ryrie BJ. Adamantinoma of the tibia: aetiology and pathogenesis. Br Med J. 1932:2(3752):1000-20

9. Imran $\mathrm{MB}$, Othman $\mathrm{SA}$. Bilateral tibial adamantinomas simulating stress fractures on scintigraphy. Clin Nucl Med. 2011;36(9):788-90.

10. Kahn LB. Adamantinoma, osteofibrous dysplasia and differentiated adamantinoma. Skeletal Radiol. 2003;32(5):245-58

11. Ulmar B, Delling G, Werner M, Huch K, Reichel H. Classical and atypical location of adamantinomas--presentation of two cases. Onkologie. 2006;29(6):276-8.

12. Bethapudi S, Ritchie DA, Macduff E, Straiton J. Imaging in osteofibrous dysplasia, osteofibrous dysplasia-like adamantinoma, and classic adamantinoma. Clin Radiol. 2014;69(2):200-8.

13. Khanna M, Delaney D, Tirabosco R, Saifuddin A. Osteofibrous dysplasia, osteofibrous dysplasia-like adamantinoma and adamantinoma: correlation of radiological imaging features with surgical histology and assessment of the use of radiology in contributing to needle biopsy diagnosis. Skeletal Radiol. 2008;37(12):1077-84

14. Scholfield DW, Sadozai Z, Ghali C, Sumathi V, Douis H, Gaston L, et al. Does osteofibrous dysplasia progress to adamantinoma and how should they be treated? Bone Joint J. 2017;99-B(3):409-16.

15. Kiral A, Pehlivan O, Cilli F, Akmaz I, Rodop O, Solakoglu C. Reconstruction of intercalary gap after wide surgical resection of adamantinoma of the tibia Orthopedics. 2008;31(11):1143.

16. Szendroi M, Antal I, Arató G. Adamantinoma of long bones: a long-term follow-up study of 11 cases. Pathol Oncol Res. 2009;15(2):209-16.

17. Sakellariou VI, Mavrogenis AF, Papagelopoulos PJ. Limb salvage surgery using the intramedullary diaphyseal segmental defect fixation system. J Long Term Eff Med Implants. 2008;18(1):59-67.

18. Frey SP, Hardes J, Ahrens H, Winkelmann W, Gosheger G. Total tibia replacement using an allograft (in a patient with adamantinoma). Case report and review of literature. J Cancer Res Clin Oncol. 2008;134(4):427-31.

19. Kirkwood BR, Sterne JA. Essential medical statistics. 2nd ed. Massachusetts: Blackwell Science; 2006.

20. Ramanoudjame M, Guinebretière JM, Mascard E, Seringe R, Dimeglio A, Wicard $P$. Is there a link between osteofibrous dysplasia and adamantinoma?. Orthop Traumatol Surg Res. 2011;97(8):877-80.

21. Filippou DK, Papadopoulos V, Kiparidou E, Demertzis NT. Adamantinoma of tibia: a case of late local recurrence along with lung metastases. J Postgrad Med. 2003;49(1):75-7.

22. Giannoulis DK, Gantsos A, Giotis D, Paschos NK, Vagionas A, Arnaoutoglou $\mathrm{CM}$, et al. Multiple recurrences and late metastasis of adamantinoma in the tibia: a case report. J Orthop Surg (Hong Kong). 2014;22(3):420-2.

23. Qureshi AA, Shott S, Mallin BA, Gitelis S. Current trends in the management of adamantinoma of long bones. An international study. J Bone Joint Surg Am. 2000;82-A(8):1122-31 